\title{
TAXONOMIC AND NOMENCLATURAL NOTES ON DALMATIAN AND MONTENEGRIN TANDONIA: OLD ISSUES SOLVED AND NEW PROBLEMS ARISE (GASTROPODA: PULMONATA: MILACIDAE)
}

\author{
WiLly De MATTIA ${ }^{1 *}$, Vladimir PeŠIĆ ${ }^{2}$ \\ ${ }^{1}$ International Centre for Genetic Engineering and Biotechnology (ICGEB) Padriciano, 99. 34149 Trieste, \\ Italy (e-mail: Willy.DeMattia@icgeb.org) \\ ${ }^{2}$ Department of Biology, Faculty of Sciences, University of Montenegro, Cetinjski put b.b., 81000 \\ Podgorica, Montenegro \\ * corresponding author
}

\begin{abstract}
We collected Tandonia at many sites in Dalmatia and Montenegro and examined the material in view of open taxonomic questions or limited knowledge of the morphology. New anatomical data strongly support the hypothesis that Amalia montenegrina Simroth, 1900 is a junior synonym of Tandonia reuleauxi (Clessin, 1887). The type locality of Tandonia cavicola (Simroth, 1916) has been recently located and, consequently, the literature data have been revised and compared with anatomical data provided by the newly collected specimens from historic localities cited for the species, but not from the type locality itself. The results show that the specimens so far referred to as $T$. cavicola could be assigned also to other nominal species, e.g. T. dalmatina (Simroth, 1900) or, less likely, to T. lagostana (Wagner, 1940). New dissections of Tandonia fejervaryi (Wagner, 1929) and Tandonia rara Wiktor, 1996 revealed new undescribed anatomical features, e.g. the internal structure of the distal female genitalia for the T. fejervaryi and the spermatophore for T. rara.
\end{abstract}

KEY WORDS: Tandonia montenegrina, T. reuleauxi, T. cavicola, T. fejervaryi, T. rara, Dalmatia, Montenegro, taxonomy, systematics, nomenclature, anatomy

\section{INTRODUCTION}

In the Western Balkans, from Istria through Dalmatia to Montenegro, the genus Tandonia Lessona et Pollonera, 1882 (type species: Amalia marginata Lessona et Pollonera, 1882 = Tandonia rustica (Millet, 1843 ) is represented by numerous species, most of them endemic (DE MATTIA \& NARDI 2014: 124, Table 1). WIKTOR $(1982,1987,1996)$ was the first to revise the species from the whole area, providing a remarkable contribution to the knowledge of the group. Nevertheless, the taxonomic validity and the systematic position of some of these taxa is yet to be properly assessed and defined. This is due, first, to inadequate descriptions and illustrations provided by the original authors (cf. SIMROTH 1900 and WAGNER 1931) and the lack of types, or recently collected ma- terial to be studied, a difficulty often experienced by Wiktor himself. These problems are, of course, not restricted to the Western Balkan Tandonia. Recently, detailed (re)descriptions have been published of new or enigmatic species, such as Tandonia totevi Wiktor, 1975 and Tandonia bolensis De Mattia et Nardi 2014 (see: SCHNEPPAT et al. 2011 and DE MATTIA \& NARDI 2014, respectively).

Amalia montenegrina Simroth, 1900 is a poorly known taxon, the identity of which has not been properly assessed. WIKTOR (1987: 269) provided a summary of what was then known and extracted what he considered to be accurate information from SiMROTH (1900: 106 and 107). He clearly stated that no type material had been found and his collecting 
activities in the localities listed by SimROTH (1900), except for "Bazar", were unsuccessful. Hence, he regarded Amalia montenegrina as a nomen dubium. Later, WIKTOR (1996: 36) confirmed what he had previously stated, but suggested that Amalia montenegrina could be a junior synonym of T. reuleauxi (Clessin, 1887). WIKTOR's (1996) opinion is shared by BANK (2013) in his comprehensive European checklist.

As part of a project aimed at a better understanding of the poorly known Montenegrin slug fauna, we investigated some of the (type) localities listed by SimRotH (1900) for A. montenegrina. We found many Tandonia specimens matching SIMROTH's (1900) description of this species. This allowed us to study topotypes and to propose a definitive identity for Amalia montenegrina Simroth, 1900 based on our own morphological investigations. We confirmed that $A$. montenegrina should be regarded as a junior synonym of $T$. reuleauxi as provisionally suggested by WIKTOR (1996: 39).

Other species of Tandonia from the Western Balkans were carefully (re)described by WIKTOR (1987, 1996). For these taxa WIKTOR's paper (1996) represents the only source of information as regards anatomy, general morphology and bionomics, and

\section{MATERIAL AND METHODS}

The localities from which the new material of Tandonia was collected are listed under the species subheadings below. The slugs were killed in fresh water and fixed in $75 \%$ ethanol. Tissue samples were preserved for future phylogenetic studies. Dissections were carried out under a Leica stereomicroscope. Anatomical details (genitalia, jaws, spermatophores) were drawn using camera lucida. Shells and bodies were measured and photographed. The material is

\section{RESULTS AND DISCUSSION}

\section{REDESCRIPTION OF AMALIA MONTENEGRINA AND ITS SYNONYMISING WITH TANDONIA REULEAUXI}

\section{Tandonia reuleauxi (Clessin, 1887)}

Figs 1-13, 20-41

Amalia montenegrina Simroth, 1900: Kotor, Žabjak, Vir Bazar (Virpazar), Rijeka (Rijeka Crnojevića).

For complete synonymy and distribution see WiKTOR $(1979,1987,1996)$.

Material examined from localities of $A$. montenegrina given in orginal description: Virpazar (province it can be certainly stated that, in most cases, these redescriptions are much more accurate and a richer source of iconography than the original descriptions.

During a survey along the Southern Dalmatian coast (Vitalijna Peninsula), two Tandonia specimens were collected with a very characteristic body colouration, resembling what SIMROTH (1900: 106) described as T. dalmatina from Dubrovnik (Croatia) or as T. cavicola (1916: 6) from the environs of Sinj (Croatia). A careful survey of the literature and the morphological study of the new material, led to the observations presented below. As a result, the identity of T. dalmatina as reported in the recent literature is questioned.

Other Tandonia specimens, collected by us in the area over a period of 12 years (from 2002 to 2014), enabled us to do additional anatomical and ecological investigations. As a result, new taxonomic (mainly morphological), biogeographical and ecological data are presented here. The other Western Balkan species investigated here are T. fejervaryi $(\mathrm{H}$. Wagner, 1929) and T. rara Wiktor, 1996.

In this paper we provide new and more explicit descriptions in this problematic group of slugs.

deposited in the collection of WILLY DE MATTIA \& JESSICA MACOR (WDM-JM) and the collection of VLADIMIR PEŠić at the Biology Department of the University of Montenegro in Podgorica. Our investigations were greatly aided by ANDRZEJ WIKTOR who confirmed the identity of some of our specimens of $T$. reuleauxi in 2001.

The abbreviation dsp in the text indicates the number of dissected specimens.

of Bar, Montenegro), 42 ${ }^{\circ} 14^{\prime} 43.01^{\prime \prime} \mathrm{N}, 1^{\circ} 05^{\prime} 31.48^{\prime \prime} \mathrm{E}$, 15 m a.s.l., V. PEŠIĆ leg., 10.10.2014, 6 dsp; Rijeka Crnojevića (Cetinje, Montenegro), 42²1’16.49”N, $19^{\circ} 01^{\prime} 41.22$ "E, 5 m a.s.l., W. DE MATTIA \& J. MACOR leg., 12.5.2014, 3 dsp; Kotor, ruins of old Castle (Montenegro), 42²5'19.71”N, 1846’29.17”E, 215 m a.s.l., W. DE MATTIA \& J. MACOR leg., 12.5.2014, 4 dsp.

Other Montenegrin material examined: Podgora (Virpazar, province of Bar, Montenegro), 42¹4'34.83”N, 1903'8.79”'E, 505 m a.s.l., V. PEŠIĆ leg., 10.10.2014, 6 dsp; 500 m WNW of Sotonići, near a small spring close to a restaurant (Virpazar, province

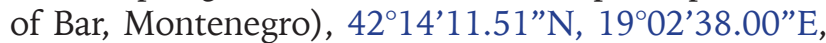
205 m a.s.l., W. DE MATTIA \& J. MACOR leg., 12.5.2014, 


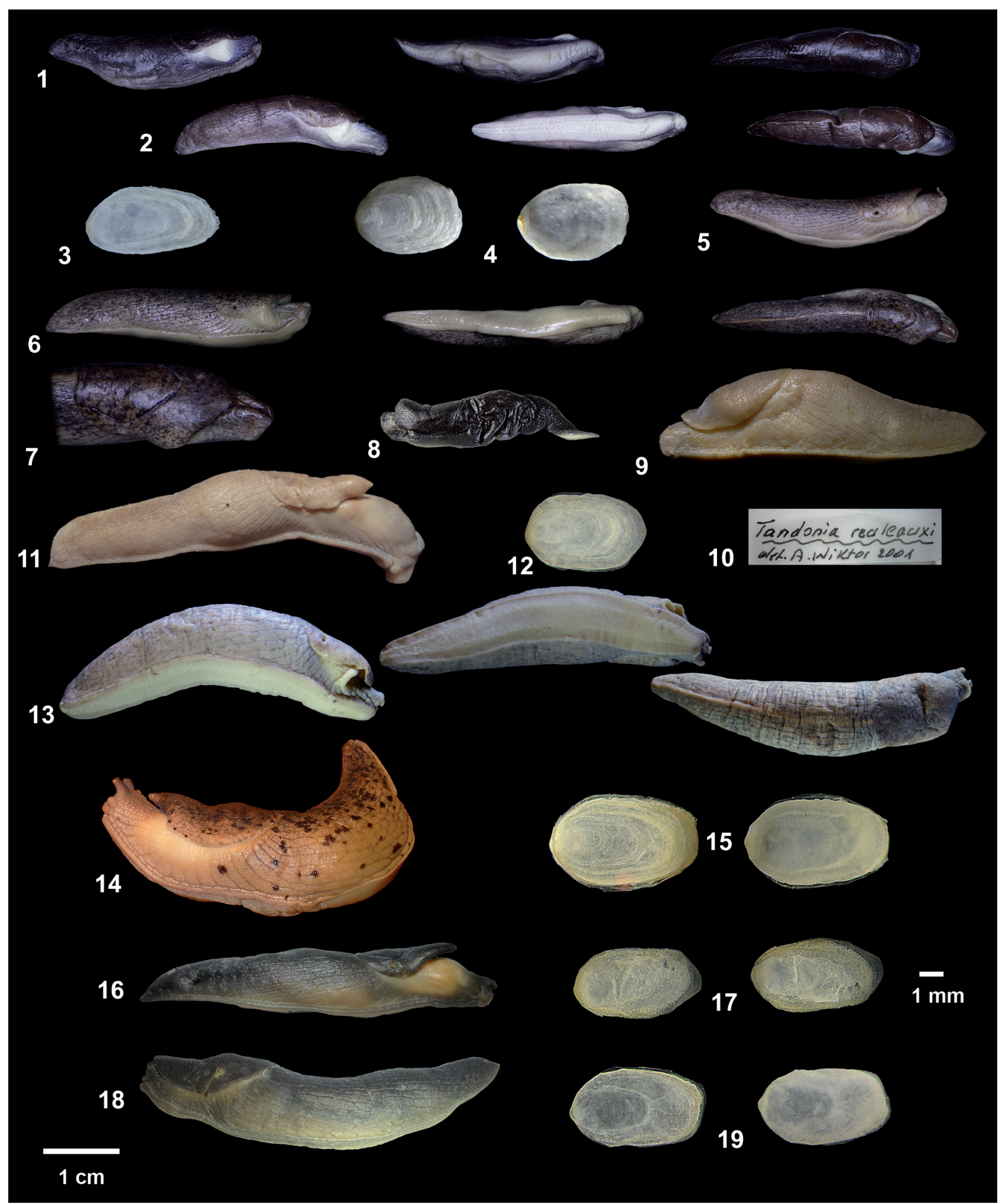

Figs 1-19. Specimens of Tandonia from Montenegro, Croatia and Italy: 1-13 - Tandonia reuleauxi: 1-2 - whole body and 3 shell from Virpazar (Montenegro), 4 - shell and 5 - right side of the body from Kotor (Montenegro), 6 - whole body and 7 - magnification $(2.5 \times)$ of the anterior body from Podgora (Montenegro), 8 - left side of the body from Rijeka Crnojevića, 9 - left side of body and 10 - A. WIKTOR's identification label from Jamiano (Gorizia, Italy), 11 - right side of the body and 12 - shell from Vrgorac (Dubrovačko-Neretvanska, Croatia), 13 - whole body from Komolac (Dubrovačko-Neretvanska, Croatia); 14-15 - Tandonia cf. cavicola from Vitalijna (Dubrovačko-Neretvanska, Croatia): 14 - left side of the body, 15 - shell; 16-17 - Tandonia fejervaryi from Starigrad Paklenica (Zadarska, Croatia): 16 - right side of the body, 17 - shell; 18-19 - Tandonia rara from Omiš (Splitsko-Dalmatinska, Croatia): 18 - right side of the body, 19 - shell. $1 \mathrm{~cm}$ scale bar is for slug bodies, $1 \mathrm{~mm}$ - for shells 
1 dsp; Risan, Catovica Mlini (Kotor, Montenegro), $42^{\circ} 31^{\prime} 6.29^{\prime \prime} \mathrm{N}, 18^{\circ} 41^{\prime} 46.55^{\prime} \mathrm{E}, 30 \mathrm{~m}$ a.s.l., V. PEŠIĆ leg., 10.x.2014, 2 dsp; Sutorina, near the border between Montenegro and Croatia (Herceg-Novi, Montenegro), $42^{\circ} 28^{\prime} 35.28^{\prime \prime} \mathrm{N}, 18^{\circ} 27^{\prime} 52.14^{\prime \prime} \mathrm{E}, 60 \mathrm{~m}$ a.s.l., W. DE MATTIA \& J. MACOR leg., 12.5.2014, 2 dsp.

Other, non-Montenegrin, material examined: Komolac, near the old cemetery (Dubrovnik, Croatia), $42^{\circ} 40^{\prime} 5.56^{\prime \prime} \mathrm{N}, 18^{\circ} 07^{\prime} 55.60^{\prime \prime} \mathrm{E}, 10 \mathrm{~m}$ a.s.l., W. DE MATTIA \& J. MACOR leg., 12.5.2014, 1 dsp; Mali Zaton, near the spring (Dubrovnik, DubrovačkoNeretvanska Zupanjia, Croatia), $42^{\circ} 42^{\prime} 6.61^{\prime \prime} \mathrm{N}$, $18^{\circ} 02^{\prime} 42.39$ "E, 3 m a.s.l., W. DE MATTIA \& J. MACOR leg., 12.5.2014, 1 dsp; road along Baćinska Jezera (Dubrovnik, Dubrovačko-Neretvanska Zupanjia, Croatia), $43^{\circ} 04^{\prime} 16.49^{\prime \prime} \mathrm{N}, \quad 17^{\circ} 24^{\prime} 36.04^{\prime \prime} \mathrm{E}, \quad 40 \mathrm{~m}$ a.s.l., W. DE MATTIA \& J. MACOR leg., 12.5.2014, 2 dsp; Vrgorac (Metkovič, Dubrovačko-Neretvanska

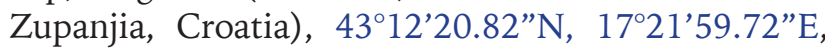
280 m a.s.l., G. NARDI leg., 15.07.2014, 1 dsp; deep crevices in a karstic doline near Tomaj (Sežana, Slovenija), 454' $52.74^{\prime \prime} \mathrm{N}, 13^{\circ} 50^{\prime} 50.30^{\prime \prime} \mathrm{E}, 315 \mathrm{~m}$ a.s.l., W. DE MATTIA leg., 18.7.2007, 2 dsp; cave "Pozzo ricovero presso Jamiano" near Monfalcone (Gorizia, Italy), 4549'37.43”N, 13³3’44.01”E, $20 \mathrm{~m}$ a.s.1., W. DE MATTIA leg., 07.01.2001/16.09.2006, 2 dsp.

Body (Figs 1-13): The length of preserved, mature specimens ranges from 30.9 to $66.1 \mathrm{~mm}$. Width was not measured: it was much affected by preservation. The keel is well developed and visible from the tail half way to the posterior mantle edge, lighter in colour that the surrounding body. The anterior portion of the keel is less sharp and less distinct, darker in colour, often the same as that of the body. The mantle length ranges from 10.5 to $17.1 \mathrm{~mm}(\mathrm{n}=16)$ and usually it represents from 32 to $42 \%$ of the total length of the slug. Dorsum length: $18.3-34.9 \mathrm{~mm}$ $(n=16)$.

The external appearance of the specimens from the localities cited as Terra Typica (Virpazar, Rijeka Crnojevića and Kotor) corresponds with the descriptions given by SIMROTH (1900: 106) as summarised by WIKTOR (1987: 38; 1996: 38). Specimens from both Virpazar and Rijeka Crnojevića are wholly slate black, with dark-violet or bluish hues along the back and sides, slightly lightening downward toward the sole (Figs 1, 2, 8). There is neither pigmentation in the grooves nor any spotting. Specimens from Podgora (Virpazar) (Fig. 5), Kotor (Figs 6, 7), and the nearby village of Risan, on the other hand, are dirty grey to brownish in colour. In Podgora and Kotor the specimens show accumulations of pigment along the wrinkles and grooves and also on the mantle. There is a more or less fine and irregular spotting, gradually denser toward the back and on the mantle. This spotting often creates areas of uniform dark colour on the back and mantle. The mucus is colourless or milk-whitish when the slug is irritated.

Totally slate black specimens are usually smaller, ranging from 30.9 to $44.6 \mathrm{~mm}$, while grey to brownish specimens are always bigger, ranging from 42.7 to $66.1 \mathrm{~mm}$. The peri-gonopore area is characterised by a lighter coloration in all specimens, often reaching a whitish shade in Virpazar and Rijeka Crnojevića.

As reported by SCHNEPPAT et al. (2011: 233) for T. totevi Wiktor, 1975 from Bulgaria and Northern Greece, the mantle surface in $T$. reuleauxi from Montenegro has fine crenellations that are also visible in preserved specimens (Fig. 7). Sometimes a horseshoe-shaped groove is present on top of the mantle (Fig. 7). The shape and size of pneumostome varies depending on the preservation process. The slit starts from the mantle border and reaches the pneumostome at its dorsal portion.

The sole is tripartite with a deep peripodial wrinkle which encircles the whole body, except along the buccal area. The central portion is whitish in colour while the two lateral portions are darker in the slate black specimens (Figs 1,2) and yellowish-creamy in the grey-brownish ones (Fig. 6). A chevron pattern is clearly visible in preserved specimens.

Jaw: oxygnathous, smooth and reddish-ochreous in colour. Sometimes blackish radial stripes are present, interposed with yellowish areas. The structure is solid and the shape is arrow-like (Fig. 31).

Shell: is typical of the genus Tandonia. It is slightly elongated, moderately convex dorsally and flat ventrally. It is sturdy and well calcified, with a granulated pattern on the ventral side (Figs 3, 4, 12).

Shell measurements $(\mathrm{n}=16)$ : length: $3.7-5.4 \mathrm{~mm}$, width: $2.7-3.9 \mathrm{~mm}$.

Genitalia (Figs 20-41): The vas deferens opens asymmetrically but apically on the proximal penial complex. The transition between epiphallus and penis is not clear. The walls of penial complex (epiphallus + penis) are thick with dense muscular tissue. The inner walls of epiphallus proximally show series of 8-11 small roundish to sub-rectangular papillae. Distally, the papillae gradually turn into more or less thin folds that end at the level of the penial papilla. Usually the papillar zone occupies from $1 / 3$ to $1 / 2$ of the space between the proximal end of epiphallus and the penial papilla (Figs 24,25). The penial papilla is simple (Figs 23,30) with an expanded, inflated lip that extends inward developing a few fringes. A thin penial retractor muscle is present, but it is often hard to detect and it can be confused with other loose connective tissues, so its precise position cannot be ascertained. Vagina and atrium short to very short. There are 6 to 12 leaf-like vaginal glands, with thin, tubular stems. Sometimes the glands are not leaf-like but tubular or rod-shaped with tapered 


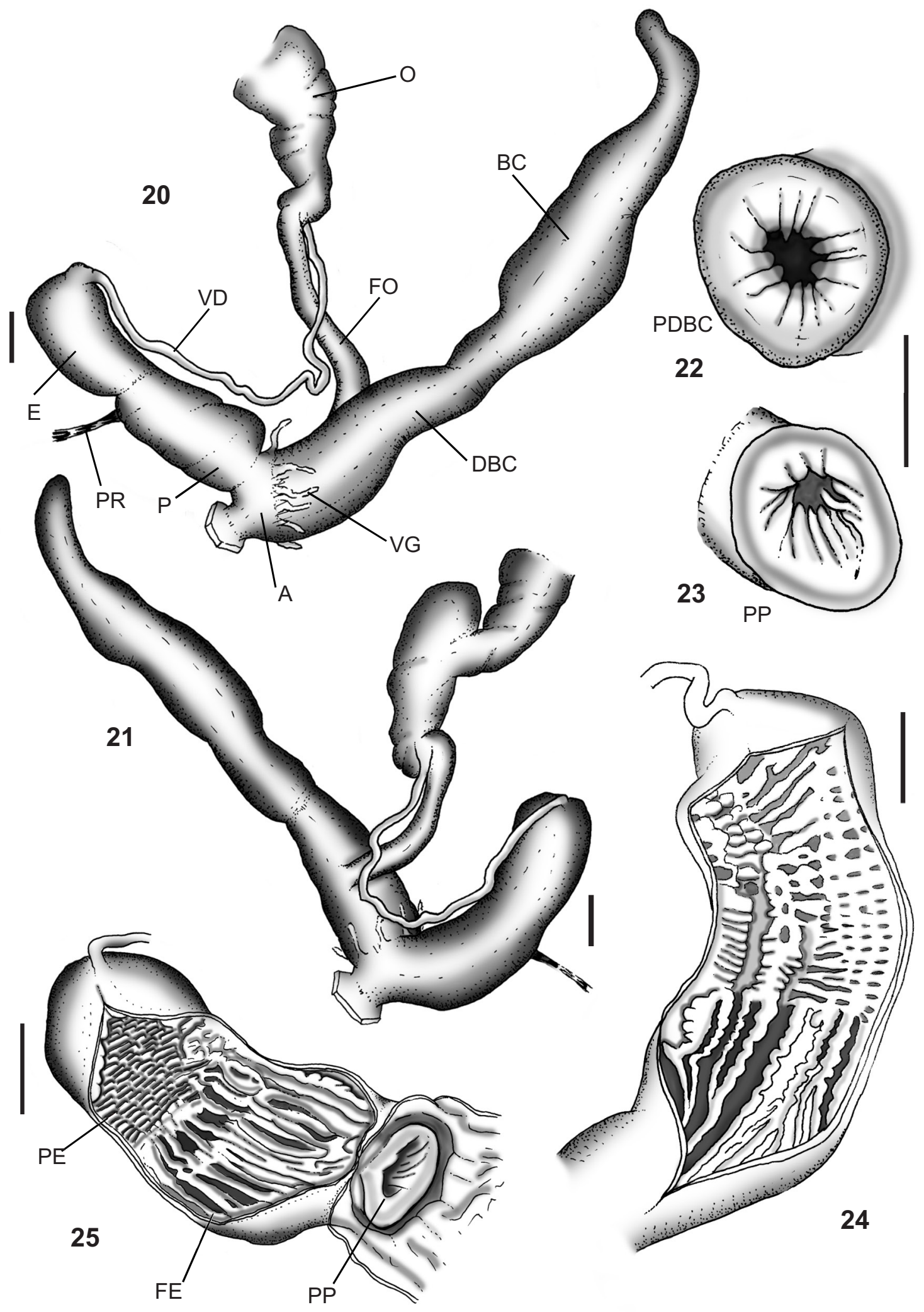

Figs 20-25. Tandonia reuleauxi from Virpazar (Montenegro): 20-21 - distal genitalia; 22 - atrial papilla of the duct of bursa copulatrix; 23 - penial papilla; 24-25 - inner structure of the penial complex. Figs 20-23 and 25 belong to specimen no. 11752, while Fig 24 belongs to specimen no. 11754 (WDM-JM coll.). Abbreviations: A - atrium, BC - bursa copulatrix, DBC - duct of the bursa copulatrix, E - epiphallus, FE - folds of distal inner epiphallus, FO - free oviduct, O - ovispermiduct, PDBC - papilla of duct of the bursa copulatrix, P - penis, PE - papillae of the proximal inner epiphallus, PP - penial papilla, PR - penial retractor, VG - vaginal glands, VD - vas deferens. Scale bars: $1 \mathrm{~mm}$ 


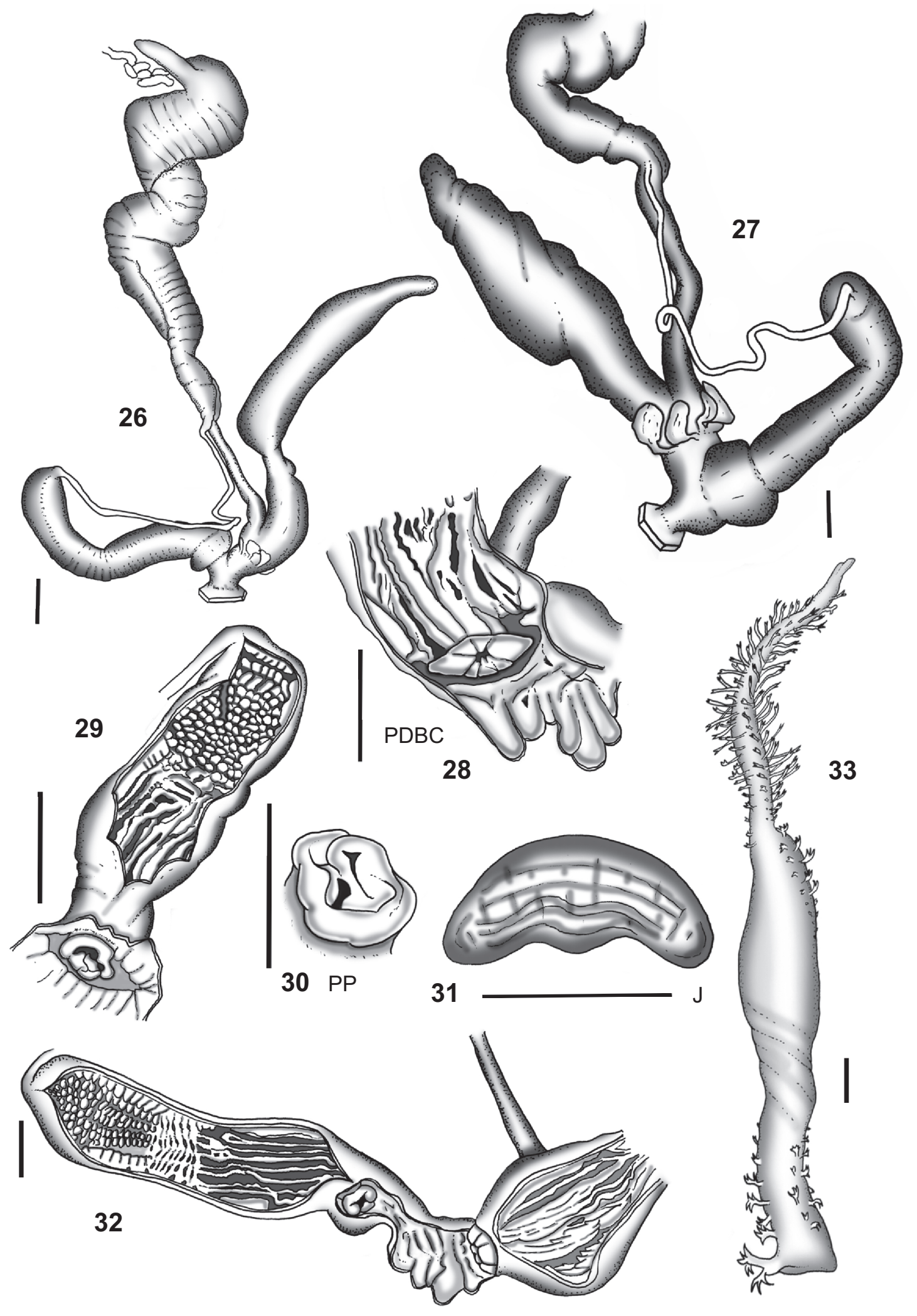

Figs 26-33. Tandonia reuleauxi: 26-27 - distal genitalia; 28 - atrial papilla of bursa copulatrix; 29 - inner structure of the penial complex; 30 - penial papilla; 31 - jaw; 32 - inner structure of the penial complex, atrium and duct of the bursa copulatrix; 33 - spermatophore. Specimens originated from: 26 \& 32 - Rijeka Crnojevića (Cetinje, Montenegro), specimen no. 11736 (WDM-JM coll.), 27-31 - Podgora (Virpazar, Montenegro), specimen no. 11739 (WDM-JM coll.), 33 - Virpazar (Montenegro), specimen no. 11754 (WDM-JM coll.). Note that in Figs. 26 and 27 the penial retractor has not been depicted as often it is not detected during the dissections. Abbreviations: PDBC - papilla of duct of bursa copulatrix, PP - penial papilla. Scale bars: $1 \mathrm{~mm}$ 
ends. The inner walls of atrium bear some large folds running from gonopore inward. The duct of bursa copulatrix is thick-walled with robust inner folds that reach the distal portion of the bursa. It opens into the atrium through a solid papilla (Fig. 22). The boundary between the duct of the bursa copulatrix and the bursa is easily recognisable, as the wall thickness drastically decreases into a thin layer of glandular tissue. The bursa is usually long, tubular and pointed, but sometimes can be rounded. The inner walls of the bursa have fine, scattered folds and papillae. The free oviduct opens distally into the side of thick-walled duct of bursa copulatrix. On the inner walls of free oviduct there are many fine folds. Spermoviduct bulky and long, proximally ending with an albumen gland.

Two spermatophores were found in specimens from Virpazar (19.5 and $21.3 \mathrm{~mm}$ long) (Fig. 33). They consist of an anterior, tubular part all around covered by numerous bi- or polyfurcated spines. The mid-portion is smooth and swollen, almost barrel-like. The terminal (tail) portion is equally swollen and covered along two sides by polyfurcated spines (also see: WIKTOR 1996: 44).

Habitat and ecology: The specimens were found crawling on limestone rocks in shaded places. The species lives in xerophilous forests, i.e. Mediterranean scrub, usually in deep crevices or first chambers of caves. It is not uncommon to find $T$. reuleauxi crawling in broad daylight during rainy periods in summertime.

Remarks on the original localities of Amalia montenegrina Simroth, 1900: We investigated three of the four Montenegrin localities provided by SIMROTH (1900: 104-105) as terra typica of the species: Kotor, Vir Bazar (sic! =Virpazar) and Rijeka (=Rijeka Crnojevića). WiKTOR (1987: 268, 1996: 36), while reporting the collecting sites of SIMROTH (1900), may have misinterpreted some of these localities. Nevertheless, WiKTOR (1996: 38) cited WOHLBEREDT (1901) to putatively associate "Vir Bazaar" with Virpazar. Conversely, the name "Rijeka" cited and located by WIKTOR (1987: 267, map 11) probably refers to the city of Rijeka (Fiume), at the northern end of the Kvarner Gulf in Croatia. However, SIMROTH (1900) specified that the localities he listed were located in "Montenegro (und Dalmatien)", so it seems more likely that "Rijeka" should be identified as the present Rijeka Crnojevića, at the northern shores of Lake Skadar.

Comparative remarks: The study of Montenegrin specimens and other $T$. reuleauxi from Croatia, Slovenia and Italy reveals a great variation of size and body colouration, despite a rather conservative and stable arrangement of the genitalia.

The body colouration varies from uniformly slate black (Virpazar, Rijeka Crnojevića) to very light uniformly creamy (Tomaj, Doberdò) with more or less brownish and spotted variations inbetween (e.g. Kotor, Komolac and Baćinska Jezera) (Figs 1, 2, 5-8). SimRoTH (1900) also reported such variation in Amalia montenegrina. Many populations of Tandonia sowerbyi (Férussac, 1823) from Montenegro resemble specimens of T. reuleauxi found nearby (e.g. from Podgora-Virpazar).

The slugs gradually become larger towards the north (see: Figs 1, 2, 9, 11). The smallest adults are slate black (Virpazar and Rijeka Crnojevića), but the grey and spotted specimens from Podgora (nearby Virpazar) become as big as those in northern Dalmatian populations.

WAGNER (1929: 337) described the body colouration of $T$. reuleauxi as: "Körperfarbe oben blauschwarz, ohne Flecke, an den seiten grau und graugelb, Sohle zitronengelb". Nevertheless he did not include Amalia montenegrina in his identification key; the Montenegrin specimens from Virpazar and Rijeka Crnojevića match this description. WeLTERSCHULTES (2012: 438) shows a slate black specimen of Tandonia sp. from Virpazar as T. reuleauxi, but the identification is not accompained by any taxonomic remark or observation.

The descriptions of the genital anatomy provided by SIMROTH (1900) are unclear and cannot be related to any species. The genital anatomy of the specimens collected at the original localities of Amalia montenegrina (Virpazar, Rijeka Cronjevica and Kotor) matches the redescription and illustrations provided by WIKTOR $(1987,1996)$ for T. reuleauxi except, partially, the internal structure of epiphallus. WIKTOR (1987: 280, fig. 186A) reported the presence of "small irregular elongate folds, smoothly running to posterior penis section". These folds were found also during our dissections (see: Figs: 24-25, 29, 32, 38), but only in the distal part of epiphallus. The papillae we found in the proximal epiphallus, most probably had been overlooked by WIKTOR $(1987,1996)$. The main genital features shared by all the population investigated follow a general common scheme that can be summarised as follows: small atrium; vaginal glands leaf-shaped, tubular or rod-like with short and thin peduncles; free oviduct inserts on the side of the thick-walled duct of bursa copulatrix; penial papilla simple with few fringes present inside; constant structure of inner walls of penial complex; the two spermatophores of specimens from Virpazar match WIKTOR's (1996) description for T. reuleauxi.

Considering these common features it is appropriate to follow WIKTOR (1996:37), and to regard our Tandonia specimens from Virpazar, Rijeka Crnojevića and Kotor as T. reuleauxi. By synonymising Amalia montenegrina and T. reuleauxi, we assume that the Tandonia specimens we collected at the original localities of A. montenegrina represent what SIMROTH (1900) dealt 


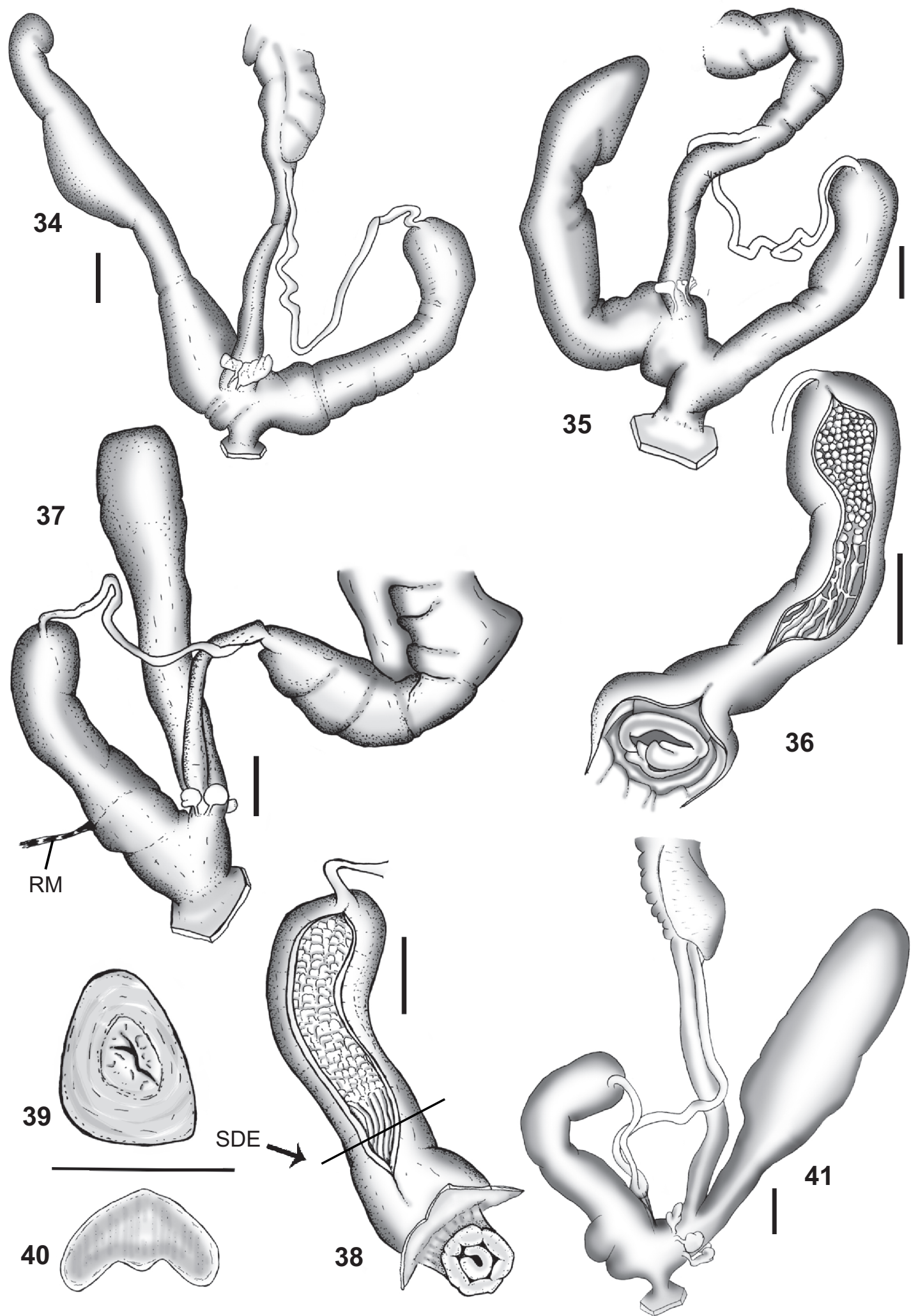

Figs 34-41. Tandonia reuleauxi: 34-35 distal genitalia; 36 - inner structure of penial complex; 37 - distal genitalia; 38 inner structure of the penial complex; 39 - section of the distal epiphallus; 40 - jaw; 41 - distal genitalia (drawing by M. BoDON, modified). Specimens originated from: 34 - Komolac, near the old cemetery (Dubrovačko-Neretvanska, Croatia) specimen no. 10996 (WDM-JM coll.); 35 \& 36 - Risan, Catovica Mlini (Kotor, Montenegro), specimen no. 11722 (WDM-JM coll.); 37-41 - Jamiano (Gorizia, Italy), specimen no. 4677 (37) and no. 4598 (38-41) (WDM-JM coll.). Note that in Figs. 34, 35 and 41 the penial retractor has not been depicted as it is often not detected during the dissections. Abbreviations: RM - retractor muscle, SDE - section of distal epiphallus. Scale bars: $1 \mathrm{~mm}$ 
with more than a century ago. Besides, we confirm that the Italian specimens referred to as Tandonia sp. in De MATTIA (2003: 154) are in fact also T. reuleauxi. This identification is confirmed by a specimen label of ANDRZEJ WIKTOR (Fig. 10). Considering these new data, the overall distribution of $T$. reuleauxi can be extended northward. Currently the species is known for Montenegro, Dalmatia, Herzegovina, southwestern Slovenia and Venetia Julia in Italy. A big hiatus seems to occur along Northern Dalmatia and Velebit, suggesting the need for more field survey. However, given the variability among the populations studied or reported in other papers, it is possible that there is a complex of T. reuleauxi forms; a molecular approach might clarify our diagnosis based solely on morphological approach.

\section{IDENTITY OF TANDONIA CAVICOLA}

\section{Tandonia cf. cavicola (Simroth, 1916)}

Figs $14,15,42-50$

Amalia cavicola Simroth, 1916: 4.

Milax (Milax) cavicola (WAGNER 1930: 50, WAGNER 1931: 65)

Tandonia cavicola (WIKTOR 1982: 470, 1996: 28, WELTER-SCHULTES 2012: 434)

Material examined: Vitaljina plateau, $1 \mathrm{~km} \mathrm{SE}$ of the small village of Misletići, along the national road 516 (Dubrovnik, Dubrovačka-Neretvanska Zupanjia, Croatia), 42²6’11.72”N, $18^{\circ} 29^{\prime} 18.53^{\prime \prime} \mathrm{E}, 140 \mathrm{~m}$ a.s.l., W. DE MATTIA \& G. TOMASIN leg., 2.01.2006, 1 dsp.; Uvala Bacvica, Prevlaka Peninsula (Dubrovnik, Dubrovačka-Neretvanska Zupanjia, Croatia), $42^{\circ} 24^{\prime} 53.36^{\prime \prime} \mathrm{N}, 18^{\circ} 30^{\prime} 34.00^{\prime \prime} \mathrm{E}$ W, $10 \mathrm{~m}$ a.s.l., W. DE MATTIA \& J. MACOR leg., 4.01.2009, 2 dsp.

Body (Fig. 14): Medium-sized slugs. The body length of preserved specimens ranges from 44 to $51 \mathrm{~mm}(\mathrm{n}=3)$, with mantle ranging from 14 to 16 $\mathrm{mm}$. The keel is moderately developed and clearly visible only along its posterior section and is light in colouur. Dorsum (from posterior mantle edge to tail tip) length: $27.8-29.9 \mathrm{~mm}(\mathrm{n}=3)$.

Specimens from both Misletići and Uvala Bacvica are uniformly ochreous-creamy. Concentrations of pigment are present in the grooves along the dorsum and mantle, thus giving the slug a dark back suddenly lightening along the sides. Darker, blackish spots are scattered on the back and sides of the body.

The tripartite sole has a deep peripodial groove which encircles the whole body, except the buccal area. The central portion of the sole is creamy-yellowish in colour while the two lateral portions are slightly darker. A chevron pattern is clearly visible in preserved specimens.
Jaw (Fig. 49): oxygnathous, smooth and reddish-ochreous in color, remarkably thin and curved, with a bow-shaped structure.

The shell shape (Fig. 15) is typical of the genus Tandonia, and irrevelant for species identification. It is slightly elongated, moderately convex dorsally and flat ventrally. It is sturdy and well calcified with a granulated pattern on the ventral side. Shell length: 6.7-6.9 mm, width: 3.9-4.1 $\mathrm{mm}(\mathrm{n}=3)$

Genitalia (Figs 42-48, 50): The vas deferens is moderately wide, roughly three times longer than the whole penial complex, and opens apically and asymmetrically. The short penial portion is moderately swollen. The walls of the penial complex (epiphallus + penis) are thick with dense muscular tissue. The inner walls of proximal epiphallus show numerous series of 7-10 small rectangular papillae. Distally, the papillae gradually turn into strong folds that end at the level of penial papilla. The papillar zone occupies from $1 / 3$ to $1 / 2$ of the space between the tip of epiphallus and the penial papilla. The penial papilla is simple, mushroom-like (Fig. 48), with an expanded, inflated lip. The lumen of penial papilla shows two lobes that originate from the inner walls. As in T. reuleauxi, a thin penial retractor muscle should be present, but it is often hard to identify and could be confused with other loose connective tissues. We did not detected its position during our dissections. The vagina is very short. There are 6 to 8 leaf-shaped vaginal glands, with thin, tubular stems. The inner walls of atrium bear some small folds, running from the gonopore inward. The duct of the bursa copulatrix is thick-walled with robust inner folds that reach the distal portion of the bursa. It opens into the atrium through a solid, multistriated papilla (Fig. 50). The boundary between the duct of the bursa copulatrix and the bursa is easily recognisable, as the wall thickness drastically decreases into a thin layer of glandular tissue. The bursa can be as long as the penial complex or only slightly longer. It is usually round-ended. The inner wall of bursa has fine folds and papillae, randomly scattered. The inner walls of free oviduct have many fine folds. Spermoviduct bulky and long, proximally ending with an albumen gland.

Habitat and ecology: The specimens were collected under calcareous rocks on a open plateau (Vitalijna) and close to the sea shore (Bacvica), both sites characterised by loosely scattered boulders and shrubby Mediterranean vegetation.

Remarks: The specimens from Vitalijna and Bacvica, by virtue of their body colouration and genital features, are probably conspecific with Tandonia cavicola (Simroth, 1916) sensu WAGNER (1931) and WIKTOR $(1982,1987,1996)$. T. cavicola was also collected from Šipan island by DRIMMER as reported by WIKTOR (1982), by WAGNER (1931) from Vitalijna (Dalmatia) and by WIKTOR $(1982,1987)$ from Zavala 


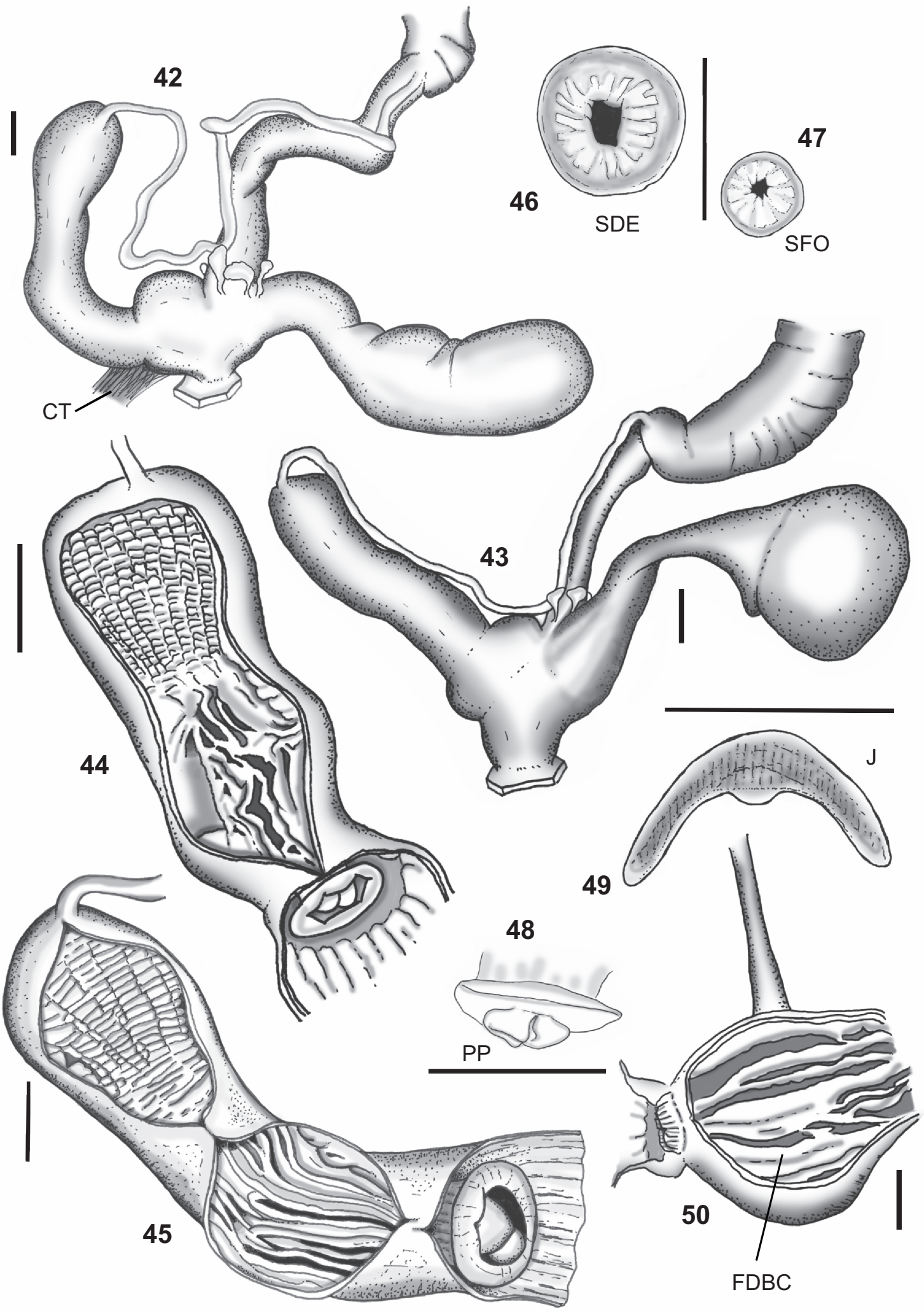

Figs 42-50. Tandonia cf. cavicola: 42-43 - distal genitalia; 44-45 - inner structure of penial complex; 46 - section of the distal epiphallus; 47 - section of the free oviduct; 48 - penial papilla; 49 - jaw; 50 - inner structure of the duct of bursa copulatrix. Specimens originated from: 42, 45-50 - Vitalijna (Dubrovačko-Neretvanska, Croatia), specimen no. 6329 (WDM-JM coll.), 43-44 - Uvala Bacvica, Prevlaka Peninsula (Dubrovačko-Neretvanska, Croatia), specimen no. 9734 (WDM-JM coll.). Note that in Figs 42 and 43 the penial retractor has not been depicted as it is often not detected during dissections. Abbreviations: CT - connective tissue, FDBC - fold of the inner duct of bursa copulatrix, PP - penial papilla, SDE - section of the distal epiphallus, SFO - section of free oviduct. Scale bars: $1 \mathrm{~mm}$ 
(Hercegovina) and Stari Bar (Montenegro). It appears that these authors considered the Southern Dalmatian and Montenegrin specimens as representing T. cavicola because of their body colouration, which matches the original description. SIMROTH (1916: 6, fig. 1) depicted a very distinctive body colouration for his species, characterised by scattered spots along the body back and sides.

Neither SIMROTH (1916), nor WAGNER (1931) and subsequently WIKTOR (1982, 1987 and 1996) had a clear idea about the exact location of the type locality of T. cavicola: Jama na Visokoj. Fortunately, BEDEK et al. (2006: 26) located the cave "na Visokoj" near the village of Radošić (43⒋ $41^{\prime} 48.64^{\prime \prime} \mathrm{N}, 16^{\circ} 36^{\prime} 8.34^{\prime \prime} \mathrm{E}$, Sinj, Splitsko-dalmatinska, Croatia) and confirmed it as the locus typicus of the species.

All the localities mentioned above are situated at least $180 \mathrm{~km}$ south of the type locality. Given this gap, and the nature of the original description (without type material), we chose to use Simroth's name as "cf.".

The first author who cited T. cavicola from the Vitalijna plateau, south of Dubrovnik, was WAGNER (1931: 65). He based his identification on the lack of vaginal glands: "an denen sich noch keine akzessorischen Geschlechtdrüsen ausgebildet haben". SimRoTH (1916: 8) did not describe the vaginal glands for T. cavicola and probably this led Wagner to use Simroth's name. Oddly, WAGNER (1931) did not take into account the peculiar spotted body colouration SimROTH (1900) described for T. cavicola. WIKTOR $(1982,1987)$ assigned his specimens from Southern Dalmatia to T. cavicola, mainly based on the distinctive spotted body colouration, but he also reported the presence of well-developed vaginal glands, including the specimen of WAGNER (1931) housed at the Natural History Museum of Vienna.

Given the unreliability of external features as taxonomic characters, it is not surprising that there is another Tandonia species whose description could match the specimens we collected from Vitalijna and Bacvica. SimrotH (1900: 106) described Amalia dalmatina from Dubrovnik, characterised by a reddish-ochreous colour with more or less densely scattered "Spritzflecken" (black spots). Distinguishing the previous description and the ochreous-creamy colour with "schwarzen Flecken" (black dots) of Tandonia cavicola (SIMROTH, 1916: 4) is difficult. Furthermore, the drawings of genitalia provided by SiMroTH (1916: 7) for Tandonia cavicola are unsatisfactory and not attributable to any species.

Obviously all records of $T$. cavicola other than that of the original description are uncertain, hence topotypical material is needed. We note that $T$. dalmati$n a$ is also known only from external features and its type locality, Rugusa (Dubrovnik), is situated not far from the localities where putative T. cavicola was re- corded. Again, examination of material from the type locality is needed.

Another poorly-known species, T. lagostana (Wagner, 1940), cannot be totally excluded as conspecific taxon, although both its external features (spot-less body colouration), and its genitalia (mainly spirally coiled epiphallus and very short duct of bursa copulatrix) appear to differ somewhat from $T$. cavicola and T. dalmatina.

While the body colouration seems to be very distinctive, at a glance the genital morphology of the two Southern Dalmatian specimens we dealt with could resemble that of T. reuleauxi. Anyhow, the penial complex of $T$. cf. cavicola is longer and tapered at its end, and the penial papilla and the papilla of bursa duct have a slightly different structure. The vas deferens is much longer than the epiphallus and penis combined, and longer than that of T. reuleauxi. The free oviduct of T. cf. cavicola is wide, larger in diameter and usually longer. It almost directly inserts into the atrium, while that of $T$. reuleauxi opens into the bursa duct.

Distribution: Because of the current taxonomic confusion, it is difficult to outline the distribution of this taxon. However, the literature and the recent records suggest that the taxon with this particular body colouration is confined to Southern Dalmatia, extending from Dubrovink as far the Montenegrin coast.

\section{NEW ANATOMICAL FEATURES OF TANDONIA FEJERVARYI AND T. RARA}

\section{Tandonia fejervaryi (Wagner, 1929)}

Figs $16,17,51-56$

Material examined: Starigrad-Paklenica (Zadar,

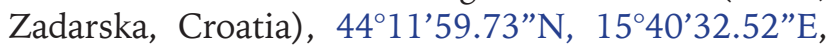
$10 \mathrm{~m}$ a.s.l., V. W. DE MATTIA \& J. MACOR leg., 16.7.2006, 2 dsp; Obrovac, along the right side of the Zrmanja River (Zadar, Zadarska, Croatia), $44^{\circ} 11^{\prime} 59.66^{\prime \prime} \mathrm{N}, 15^{\circ} 40^{\prime} 32.59^{\prime \prime} \mathrm{E}, 7 \mathrm{~m}$ a.s.l., W. DE MATTIA \& J. MACOR leg., 18.7.2006, 3 dsp.

\section{Tandonia rara Wiktor, 1996}

\section{Figs 18, 19, 57-64}

Material examined: Cetina gorge, near the first tunnel after Omiš (Split, Splitsko-Dalmatinska, Croatia), $43^{\circ} 26^{\prime} 32.27^{\prime \prime} \mathrm{N}, 16^{\circ} 43^{\prime} 52.17^{\prime \prime} \mathrm{E}, 3 \mathrm{~m}$ a.s.l., W. DE MATTIA \& J. MACOR leg., 22.10.2008, 4 dsp.

Tandonia fejervaryi (Wagner, 1929) and Tandonia rara Wiktor, 1996 were recently treated by WIKTOR $(1987,1996)$ who provided the main anatomical features. T. fejervaryi has a limited distribution along the Southern Velebit Mountains whereas T. rara is spread from Velebit to Central Dalmatia (Biokovo Mountains). 


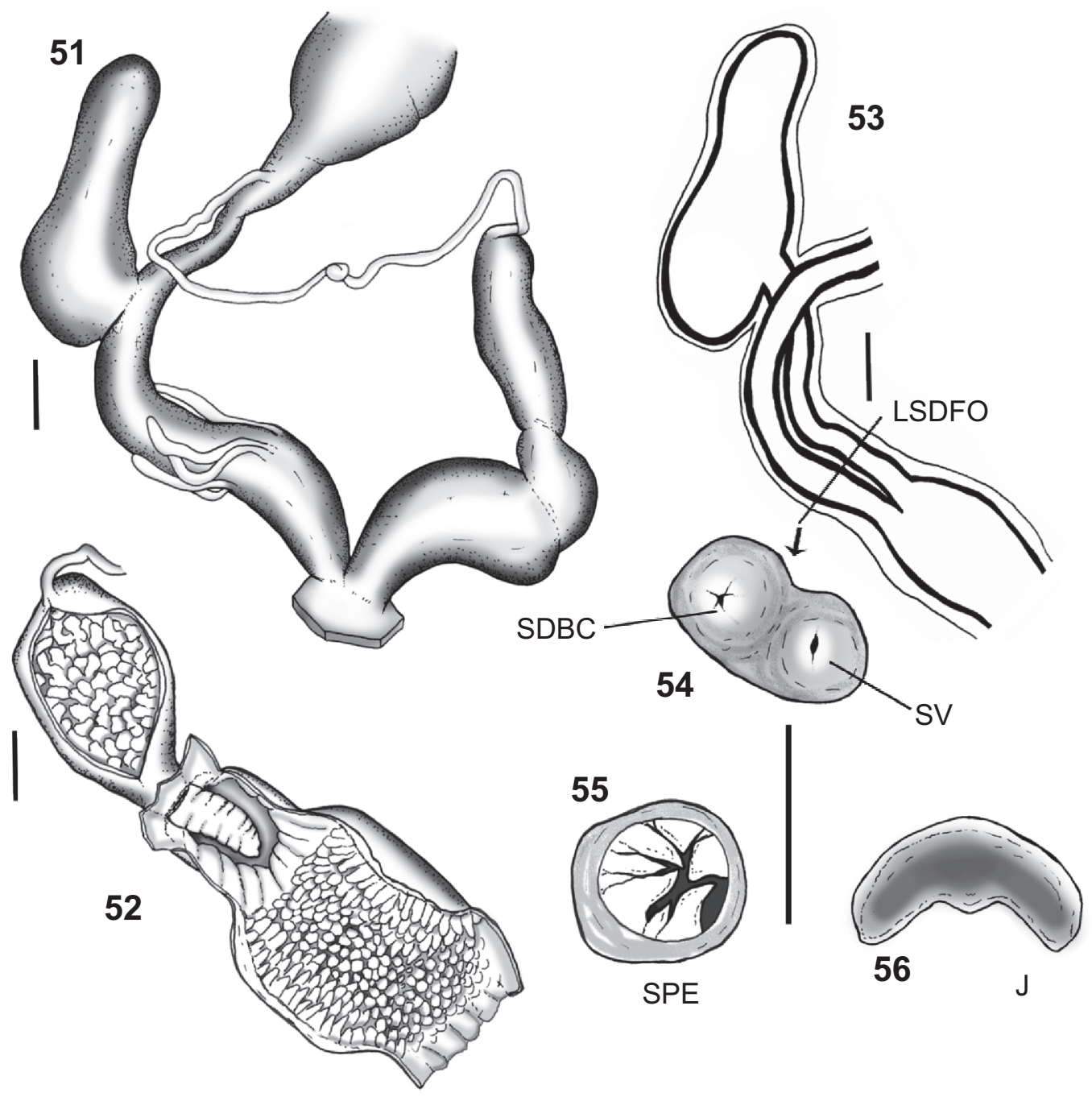

Figs 51-56. Tandonia fejervaryi from Starigrad Paklenica (Zadarska, Croatia), specimen no. 6891 (WDM-JM coll.): 51 - distal genitalia; 52 - inner structure of the penial complex; 53 - longitudinal section of the duct of bursa copulatrix and free oviduct; 54 - section of duct of bursa copulatrix with section of vagina; 55 - section of proximal epiphallus; 56 - jaw. Note that in Fig. 51 the penial retractor has not been depicted as it is often not detected during the dissections. Abbreviations: LSDFO - longitudinal section of the duct of bursa copulatrix and free oviduct, SDBC - section of the duct of bursa copulatrix, SPE - section of the proximal epiphallus. Scale bars: $1 \mathrm{~mm}$

Remarks on anatomical features: Before the work of WIKTOR $(1987,1996)$, the body colouration and the genitalia of T. fejervaryi were known only as a couple of sketches provided by WAGNER (1929: 331). These illustrations highlighted the main dagnostic features of the genitalia, viz. the very long vagina and the almost totally lacking bursa duct that arises directly from the distal portion of the free oviduct. WIKTOR (1987: 248, fig. 135) shows the inner structure of the "vagina“ and highlights the presence of a "somewhat thicker [wrinkle] separating [its] interior into two parts: one leading to oviduct and the other to spermatheca". Thus, according to WIKTOR (1987), the vagina is of great length (as a Tandonia species) and the lack of the bursa duct is confirmed. However, many cross sections of the „vagina“ (Fig. 54) reveal the presence of two parallel ducts: the duct of bursa copulatrix and the free oviduct, running far beyond the intersection point visible from the outside. Both ducts (bursa duct and distal free oviduct) are tightly enclosed by a muscular sheath, and merge at the level of vaginal glands (Fig. 53). As a result, the vagina is in fact much shorter than its external appearance suggests.

Tandonia rara was described by WIKTOR (1996: 39) from Knin (Croatia). After its description, the species and its anatomical features were never illustrated again. Finding many specimens in the Cetina valley near Omiš (Croatia) allowed us to discover some new anatomical features. The spermatophore (Fig. 64) is 18.6 to $21.4 \mathrm{~mm}$ long $(\mathrm{n}=3)$. The first part, $2 / 3$ of the total length, is smooth, club-like and gradually narrowing toward the tail, ending with a blunt apex. The second part, 1/3 of the total length, 


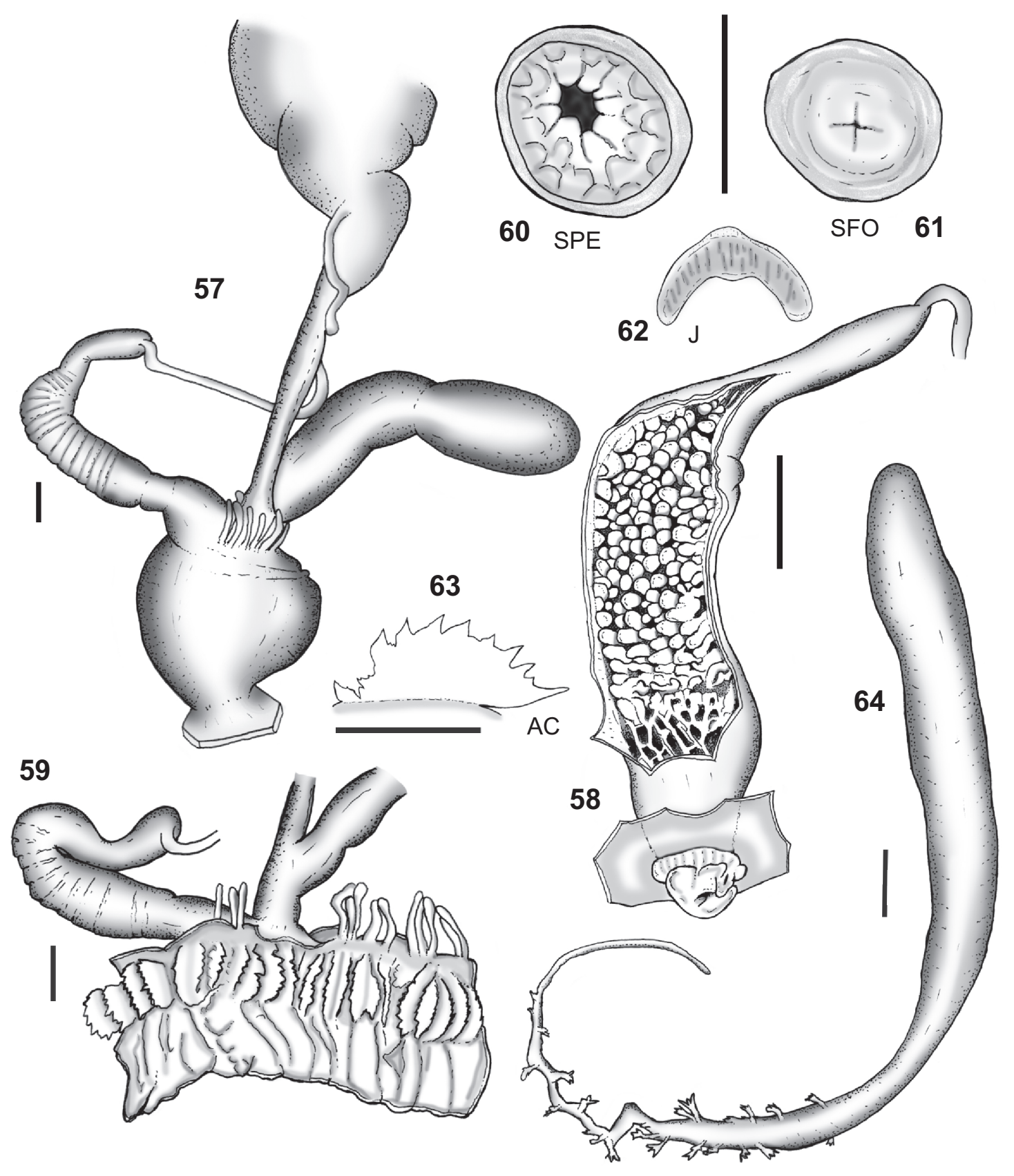

Figs 57-64. Tandonia rara from Omiš (Splitsko-Dalmatinska, Croatia), specimen no. 8155 (WDM-JM coll.): 57 - distal genitalia; 58 - inner structure of the penial complex; 59 - inner structure of atrium; 60 - section of proximal epiphallus; 61 - section of the free oviduct; 62 - jaw; 63 - atrial crest; 64 - spermatophore. Note that in Fig. 57 the penial retractor has not been depicted as it is often not detected during the dissections. Abbreviations: AC - atrial crest, SFO - section of the free oviduct, SPE - section of proximal epiphallus. Scale bars: $1 \mathrm{~mm}$

is randomly covered by few two-three tipped spines. The very last portion is thin, spineless and flagelliform. The spermatophore of T. rara, at first glance, resembles that of T. robici (WIKTOR 1996: 44, fig. 62) but there is some essential difference in the latter: the sharp and pointed apex of the first, smooth part; the spiny section proportionally longer (more than $1 / 3$ of total length as in T. rara) and the lack of a long, spineless and flagelliform portion. The inner walls of the epiphallus are covered by many large, bulky, rounded papillae (Fig. 58), turning into a vaguely re- ticulated pattern just proximally to the penial papilla. As in T. reuleauxi, a thin penial retractor muscle should be present, but it is often hard to identify and could be confused with other loose connective tissues. We did not detected its position during our dissections. The penis is very short and the penial papilla almost opens into the atrium. The atrium is large, and its proximal inner walls are covered by a series of 19-22, radially-arranged spiny crests (Figs 59, 63). The jaw is slim and moderately curved (Fig. 62). 


\section{CONCLUSIONS}

The study of Montenegrin specimens of T. reuleauxi allowed us to clarify the status of an old, ill-defined name: Amalia montengrina. Nonetheless, several other poorly-known nominal species remain to be dealt with, such as T. cavicola, T. croatica, T. dalmatina, T. jablanacensis, T. lagostana and T. robici, while new species keep on being discovered (e.g. T. bolensis from Southern Dalmatia). Even with well defined species, such as T. fejervaryi and T. rara, additional studies and dissections reveal new anatomical features, neces- sary for a more complete taxonomic placement of these taxa.

\section{ACKNOWLEDGEMENTS}

We wish to thank JESSICA MACOR (Trieste, Italy) for her companionship during the collecting trips in Dalmatia and Montenegro, and ROBERT A. D. CAMERON, THIERRY BACKELJAU, ANDRZEJ WIKTOR and HEIKE REISE for their valuable critical revision of the manuscript.

\section{REFERENCES}

BANK R. A. 2013. Fauna Europaea: Mollusca Gastropoda. Fauna Europaea version 2.6.2 Lastupdate: August 29th, 2013. http://www.faunaeur.org/

BeDEK J., GotTSTEIN MATOČEC S., JALŽIČ B., OZIMEC R., ŠTAMOL V. 2006. Catalogue of the cave type localities of Croatian fauna. Natura Croatica 15, Suppl. 1: 1-154

DE MATtia W. 2003. I molluschi ipogei del Carso Triestino (Friuli-Venezia Giulia, Italia) (Gastropoda: Architaenioglossa, Basommatophora, Stylommatophora; Bivalvia: Pterioida). Check-list delle specie, tassonomia, sistematica, ecologia e biogeografia Atti Museo Civico Storia Naturale Trieste 50: 89-218.

De Mattia W., NARdi G. 2014. Tandonia bolensis n. sp., a new slug (Gastropoda: Pulmonata: Milacidae) from the island of Brač (Dalmatia, Croatia). Ecologica Montenegrina 1: 123-130.

SCHNePpat U. E., GeORGIEV D. G., DEDOV I., WONDRAK G., KNECHTLE F. 2011. Tandonia totevi (Wiktor, 1975) (Pulmonata: Milacidae) in Bulgaria and North Eastern Greece. Redescription. Folia Malacol. 19: 225-248. http://dx.doi.org/10.2478/v10125-011-0025-4

SimROTH H. 1900. Über einige Nacktschnecken von Montenegro und Corsica. Nachrbl. Dtsch. Malakozool. Ges. 5/6: 77-85 \& 7/8: 97-107.

SimRoth H. 1916. Ueber einige von Herrn Dr. Absolon in der Herzegowina erbeutete höhlenbewohnende Nacktschnecken. Nachrbl. Dtsch. Malakozool. Ges. 48: $1-16$.

WAGNER H. 1929. Adatok a Milax-nem ismeretéhez. Beiträge zur Kenntnis der Gattung Milax. Ann. Hist.Nat. Mus. Nat. Hungarici (Pars Zool.) 26: 327-338.
WAGNER H. 1930. Morphologische und anatomische Studien an Milax. Zool. Anz. 88: 39-57.

Wagner H. 1931. Die in die Unterfamilie Parmacellinae gehörenden Formen des Naturhistorischen Museums in Wien. Ann. Nat.-Hist. Mus. Wien 46: 57-76.

WELTER-SCHULTES F. W. 2012. European non-marine molluscs, a guide for species identification. Planet Poster Editions, Göttingen.

WiKTOR A. 1979. The taxonomic status of the genus Aspidoporus Fitzinger, 1833 and remarks on Tandonia reuleauxi (Clessin, 1887) (Mollusca, Pulmonata). Ann. Zool. 35: 43-52.

WIKTOR A. 1982. Contributions to the knowledge of the slugs of Yugoslavia (Arionidae, Milacidae, Limacidae, Agriolimacidae - Gastropoda, Pulmonata). Ann. Zool. 36: 465-489.

WikTOR A. 1987. Milacidae (Gastropoda, Pulmonata) systematic monograph. Ann. Zool. 41: 153-319.

WikTOR A. 1996. The slugs of the Former Yugoslavia (Gastropoda terrestria nuda - Arionidae, Milacidae, Limacidae, Agriolimacidae Pulmonata). Ann. Zool. 46: $1-110$.

WOHLBEREDT O. 1901. Ein conchyologischer Ausflug nach Montenegro nebst einem Verzeichnis der bisher daselbst gefunden Mollusken. Abh. Naturforsch. Ges. Görlitz 13: 1-12, 193-210.

Received: April 18th, 2015

Revised: May 31st / June 11th, 2015

Accepted: June 18th, 2015

Published on-line: August 17th, 2015 